\title{
The Conundrum of Oil Prices, Stock Returns and Exchange Rate
}

\author{
ASAD KHAN \\ Department of Management Sciences \\ University of Haripur, Pakistan \\ asadkhan@uoh.edu.pk \\ ABDUL QADIR SHAH \\ Department of Management Sciences \\ University of Haripur, Pakistan \\ ZIA UR REHMAN \\ Department of Management Sciences, \\ University of Haripur, Pakistan \\ MUHAMMAD IBRAHIM KHAN \\ PhD-Scholar, Birmingham City University, United Kingdom
}

\begin{abstract}
This study imperially investigated the impact of oil prices and exchange rate on stock returns over the period of demand driven oil shock from 2001 to 2008 and supply driven oil shock from 2009 to 2016. To further explore the variation due to frequency of data, the study used daily, weekly and monthly data. The data was analyzed by applying Johansen Cointegration test, Vector error correction model, Granger causality test and Impulse response function. The Johansen Cointegration and vector error correction models confirm the long run relationship between oil prices and stock returns in all six samples. In short run, oil prices and exchange rate are not associated with the changes in stock returns. However, during demand driven oil price shocks, results confirm bidirectional relationship between oil prices and stock return.
\end{abstract}

Key Words: PSE, Cointegration, Vector Auto Regression, Oil Prices, Stock Return.

\section{Introduction}

Historically the oil prices are considered as one of the most important economic driver for growth and development, but its importance was reconfirmed by the oil crisis in 1970s (Kilian 2008). The primary work by Hamilton (1983) to confirm the influence of oil price on economic variables put the foundation for further research. Traditionally the oil prices have played a significant role in a country's economy in terms of revenues for oil producing countries and as expense for oil importing countries. Previous studies (such as Kilian (2009); Kilian and Park (2009); Lippi and Nobili (2012)) have reported two phases of oil price shocks which are Demand Driven and Supply Driven. Demand Driven Oil Price Shock (measured over the period 2001-08) is measured through stagnant supply and increasing demand (Kilian, 2009). Rapaport (2010) argued that, crude oil is an asset and derives its price from its demand and changes in oil prices and inventories are 
determined on the expectations of forward looking traders. On the other hand, Supply Driven Oil Price Shock (identified over the period from 2009 to2016) is determined on the basis of shocks in oil supply to the global markets (Baffes, Kose, Ohnsorge \& Stocker, 2015). However, Austin (2014) argues that the oil prices are determined by both the forces of supply and demand in global markets. While other studies asserted that shocks to oil prices by demand are associated with the global business cycle, which brings large changes in oil prices as seen in 1973, 1979 and 2008 (Fernández, SchmittGrohé, Uribe, 2017).

Researchers have been historically intrigued by oil prices because of its implications for the economy and corporations, at global and national levels, especially of the developed world. But lately, the subject matter has attracted the attention of researchers from developing world, with changing scenarios and its importance (Arouri \& Nguyen, 2010). While examining the data on 34 developing countries, Ramos and Veiga (2011) reported that developing countries (such as Pakistan, Bangladesh etc.) are more at risk to changes in oil prices, as their growth drives (employment, investment etc.) are highly energy sensitive (Bhar and Nikolova, 2009). Likewise, Yu and Hassan (2008) reported that as developing economies are sensitive to oil prices, changes in oil prices can negatively affect the affairs of policy makers and political governments. Thus creating political turmoil, which in turn negatively impact the closely attached stock markets. Moreover, Hamilton (2009) reported that increase in oil prices affect the stock prices negatively in two ways; first through higher production cost and second through reduction in demand for industrial products (in consistent with LeBlanc and Chinn, 2004). Thereby, it can be concluded that stock returns will be negatively affected in case of increase in oil prices and positively affected during fall in oil prices (as reported by Degiannakis, Fillis \& Kizys, 2014).

Exchange rate and its relation with oil prices and stock returns is an area of consistent interest for academia. The rational for such great interest stem from the argument that, depreciation of domestic currency makes a county's exports cheaper in international market, and results in higher demand of their exports. As a result, the stock returns of export oriented firm's listed on stock exchange will increases which will attract foreign investment in their stocks. This will cause an increase in foreign capital inflow and favorable impact on the exchange rate. However, studies conducted by Jorion (1991); Bodnar and Gentry (1993) and Bartov and Bodnar (1994) reject the positive relationship exist between exchange rate and stock returns. Rather they reported that unfavorable fluctuation in the international oil prices and exchange rate will create economic difficulties for the concern country.

Review of literature shows that majority of the studies conducted on association of oil prices, stock returns and exchanges rate are either on large oil importing Western countries or on oil exporting countries such as Park and Ratti (2008) in US; Papapetrou (2001) in Greece; Sadorsky (2001), Boyer and Filion (2007) examined the Canadian market; El Sharif, Brown, Nixon, \& Russell (2005) focused on UK. While limited studies have been conducted on emerging economies, thus there is clear need to fulfill that literature gap (Mohanty et al., 2011). Therefore, this study will examine the relationship between oil prices; stock returns and exchange rate in order to contribute to the literature gap exist regarding developing countries such as Pakistan. Second rational for 
undertaking this research is Pakistan dependency on oil imports and its effect on economy in the context of fluctuation in oil prices. Previously, the increase and decrease in oil prices have significantly contributed toward the fluctuation of balance of payment, such as low oil prices leads to high consumption of oil and increase in import bill etc. (Salah-Uddin, 2016). The Figure 1 in pie chart represents the proportion of oil consumption by the different segments of economy, highlighting the significance of oil for industrial and transport sectors.

\subsection{Pakistan's Dependence on Crude Oil}

The economy of Pakistan is hugely dependent on import of oil for its energy needs, which constitutes 30-35\% of its import bill (Daily Times, 2015). Let alone in financial year 2014-15, Pakistan imported crude oil worth \$11.7 billion (Muzamil, 2015). Crude oil, being a major cost in the government imports and business sector, variations in its price, greatly impacts the industry, local consumption, and the government's balance of payments. The same fact is observed when prices of oil drop, because it benefits the balance of payments and economy, as they heavily depend upon oil. Circular debt drops with a decline in oil prices, which in turns benefits the industry and ordinary consumers by the availability of cheap electricity. With oil prices being favorable, the energy sector, generates more to its capacity and also increases its utilization (Salahuddin, 2016).

Figure 1: Energy Consumption 2015-16

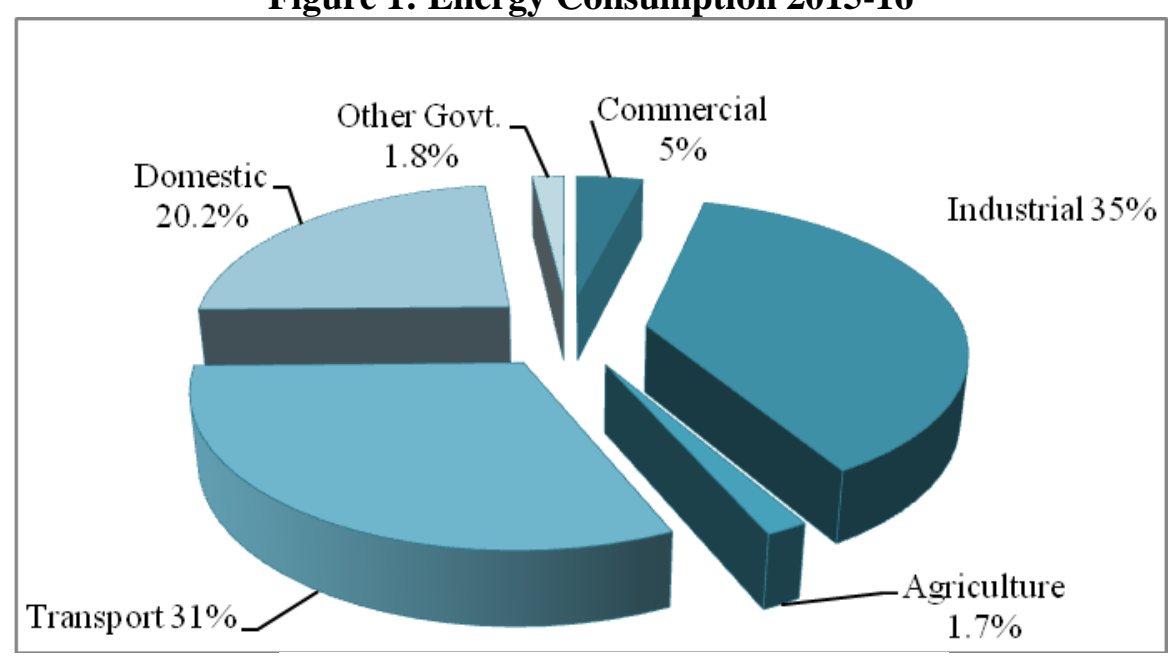

Source: Ministry of Petroleum \& Natural Resources

\subsection{Stock Market and Volatility}

Generally in develop economies the stock markets and its economies move in the same direction and have a significant relationship (Degianakis, Filis \& Floros, 2011). Thereby considering the performance of Pakistan Stock Exchange (PSE) especially in past few years (PSE is ranked as best performing markets for the third consecutive year) the other economic fundamentals should also show the same trends (Khan, 2015). But, despite tremendous growth and performance, the volatility in Pakistan Stock Exchange is always on the higher side (Arshjad \& Bashir, 2015). This phenomenon was also identified by Farid and Ashraf (1995) and further argued that these sudden crashes in 
Karachi stock market are not natural but deliberate to bring the prices to normal after abrupt movements. Thus, to increase the trust of investors and establish transparency and stability, the three stock exchanges, Karachi Stock Exchange (KSE), Lahore Stock Exchange (LSE) and Islamabad Stock Exchange (LSE) were merged together to form the Pakistan Stock Exchange (PSX), with total listed companies of 555 and a market capitalization of $\$ 67$ billion in total (The Nation, 2016).

Third this study will informed the investors about the relationship between oil prices, exchange rate and stock returns. As Khurrum (2015) documented that recent fall in oil prices result in fall of $11.7 \%, 9.3 \%$ and $9.4 \%$ in the stock prices of POL, OGDCL and PPL. Thus the study findings will benefit the investors in verifying the risk return tradeoff in response to fluctuation in oil prices at different time frames (supply and demand shock). Section two of this study covers the existing literature on relationship between oil price volatility and stock returns. Methodology is explained in section three and section four covers the result of different statistical tests. In section five, conclusions are drawn from the results in accordance with the theory developed.

\section{Literature Review}

Extensive literature is available on the association of volatility in oil prices and stock return but the findings are varied, especially in case of developing economies (Cunado \& De Gracia, 2014). According to Kling (1985), increase in oil prices has negative impact on the stock markets. Further, the study argued that continuous and long run volatility of oil prices expose the equity investors with some bitter scenarios such as diminishing cash flows and difficulty to raise new capital. Firms who have stable balance sheets will be negatively affected but those with high financial leverage will be wiped out of the scene (Milstead, 2015). The studies conducted by Jones and Kaul (1996) came with negative association, while at the same time insignificant relationship was suggested in research studies of Chen, Roll and Ross (1986); Huang, Masulis, and Stoll (1996). Yet other believes that changes in oil prices are themselves result of macroeconomic changes (Sadorsky, 2001; Hamilton, 2003). Furthermore, as the dependence of the industrial sector has grown more on oil, researchers have laid great emphasis on exploring the relationship between oil prices and stock market returns (Arouri, Boubaker \& Nguyen, 2013; Cuando \& de Garcia, 2014; Kang, Ratti \& Yoon, 2015). By using daily data Narayan and Sharma (2011) concluded that stock returns of small firms are positively affected by oil prices while negative association was predicted for larger firms.

In developed world the prices of oil is considered as an important tool in economic growth. As identified by Bernanke (1983) that fluctuation in oil prices will affect the cost of production and earning of the firm and may results in postponement of capital expenditure for growth and expansion. By examining the sensitivity of equity returns to oil prices in Australia, Faff and Brailsford (1999) established a positive relationship in all sectors, apart from Paper and Packaging, Banking and Transport industries, where they witnessed a negative relationship between oil prices and stock market returns. Similarly Sadorsky (2001) suggested that a hike in oil prices directly increase stock returns and an increase in exchange rates negatively impacts the returns of oil and gas firms listed on Toronto Stock Exchange. A study conducted by El-Sharif et al., (2005) on gas companies of Canada and UK, and confirmed positive relationship between oil prices and real stock returns. Similarly, the real stock returns of 13 European 
countries and the U.S. are significantly affected by increased fluctuations in oil prices (Park \& Ratti, 2008). But, Kilian and Park (2009) argue that supply and demand driven oil shocks result in only one fifth of the total variation in stock returns and other factors are also important to explain those long run variations. Likewise, study conducted in Norway, Bjornland (2009) found that whole economy of Norway responds directly with favorable oil prices, but this response is not a great one as $10 \%$ increase in oil prices results in only $2.5 \%$ increase in stock returns. Broadstock and Filis (2014) proposed that the relationship between changes in oil prices and stock returns is different for different countries, specifically in the context of oil producing and consuming countries. As whole aggregate demand shocks induce a moderate positive correlation with stock returns till 2011, while correlation between supply side shocks and market returns is almost negligible.

In case of emerging markets such as Shanghai and Shenzhen stock markets in China, Cong, Wei, Jiao and Fan (2008) found that oil prices fluctuations does not impact stock market returns. Similarly Broadstock and Filis (2014) suggested that relationship between oil prices and stock returns varies with time and compared to China, U.S. stock markets are more responsive to fluctuation in oil prices. Whereas Lin, Fang and Cheng (2010) suggest significant positive impact of global supply driven oil shocks on stock returns in China but in significant demand driven shocks for Hong Kong. But study conducted by Negi, Chakraborty and Mathur (2011) recommended a long term relationship between oil prices and stock returns of India and China. In case of GCC countries Arouri and Fouquau, (2009) concluded that oil prices fluctuations establishes a significant relationship with stock market returns. Similarly, Arouri, Lahiani, and Nguyen (2011) found that there is significant volatility spill over, in half of the six GCC economies, between oil prices and stock market returns.

The fluctuations in oil prices and stock returns in 22 emerging economies by Maghyereh (2004) confirm that these markets are inefficient to transmit this information into its trading activities. In another study, Basher and Sadorsky (2006) established that impact of increasing oil prices on stock market returns is positive for daily and monthly data while decreasing oil prices have positive effect for weekly data on returns of 21 emerging stock markets. Nandha and Faff (2006) studied the stock markets of Pakistan, Sri Lanka and India for a period of 1983 - 2005, and concluded that in long run many industries in these countries, including chemicals, food processors, engineering and machinery and transport are significantly sensitive to fluctuations of oil prices while in short run there is no such sensitivity between returns and oil prices. A study conducted by Raheman, Sohail, Zulfiqar and Noreen (2012) using VAR, found that fluctuations in oil prices does not significantly impact the stock returns of 11 emerging countries except for Sri Lanka and Pakistan. In Vietnam, Paresh (1993) found that the relationship among oil prices, stock prices and exchange rates are co-integrated and fluctuations in oil prices and have a positive significant impact on stock prices. Tehran Stock Market was examined by Maboudian and Shokri (2015) and found contrarily that there is no significant impact of oil supply shock, while the impact of aggregate demand, oil specific and stock specific shocks persists for 3, 6 and 2 months. Similar findings were drawn by Apergis and Miller (2008), by examining a sample of eight countries that stock markets here are not sensitive to the fluctuations in oil prices, significantly. In Pakistan, Ansar and Asghar (2013) and 
Siddiqui (2014) found in their studies that oil prices have a positive relationship with stock markets returns at KSE. Whereas in energy intensive sectors such as chemicals, fertilizers and textile industries of Pakistan, Arshjad and Bashir (2015) found that oil prices, gas prices, exchange rate and interest rate have negative impact on stock returns.

\section{Research Methodology}

This study analyzed the changes in KSE-100 index with changes in global oil prices and exchange rate in past sixteen years, using time series data starting from $2^{\text {nd }} \mathrm{Jan}$, 2001 till $30^{\text {th }}$ Dec, 2016. The time frame under study is divided into two different phases, as suggested in past studies of Kilian, (2009); Kilian and Park, (2009); Lippi and Nobili, (2012). First phase is categorized by demand driven oil prices shocks, starting from early 2001 till late 2008. The later phase which signifies supply driven oil prices, starts from early 2009 till late 2016. Further, these phases are associated with major industrial and global economic shift especially in the context of global financial crises (Tsai, 2015). Similarly in the past two decades, the international oil prices fluctuated considerably, but the psychological mark of $\$ 40$ was touched only few times (Colombo, 2015; Zhou \& Shenk, 2015; Moore, Raval \& Wigglesworth 2016; Katakey, 2017;).

\subsection{Sample}

The effect of demand driven and supply driven oil prices shocks on stock returns is investigated by using three different types of data sets (daily, weekly and monthly) in each time frame (Basher \& Sadorsky, 2006). Most of the recent studies have used high frequency data sample (Narayan \& Sharma, 2011), but we were interested to explore the distinctive response of stock returns to oil shocks at different level of data sets. Moreover, the low frequency data may not comprehend the relationship between oil prices and stock returns (Arouri, 2011). Similarly the stock markets adjust quickly to new emerging information, hence may not predict the relationships in low frequency monthly/annual data (Sadorsky, 2008). Furthermore, different investors have different investment horizons, for their returns and portfolio adjustments, so different time frames and frequency can be key factors in investor decision making. (Barberis, 2000; Grinblatt \& Keloharju, 2000).

\subsection{Variables}

For the purpose of measuring this relationship, three variables are taken; oil prices and exchange rate of Pak Rupee are the independent variables, and stock returns are the dependent variable.

The KSE 100 index is used as a proxy for stock returns.

$\mathrm{R} \_K S E=$ In (KSE 100 index $t /$ KSE 100 index $\left.{ }_{t-1}\right)$

Where R_KSE is return on KSE 100 index at given time, KSE 100 index $t$ is closing price of KSE 100 index, KSE 100 index $t$ - 1 represents opening prices (or pervious day closing), and $\mathrm{In}$ is the natural $\log$.

The proxy for oil prices is Brent, which is a global benchmark; and represent $60 \%$ global crude oil trade (Bouri, 2015). Although differences do exist between Brent and others, such as West Texas Intermediate, Dubai etc., but it is not that significant (Maghyereh, 2004). The Brent prices were converted to Pak Rupee (PKR) by multiplying with respective day exchange rate. Then the oil prices were deflated by Consumer Price Index (CPI) of Pakistan to obtained the real prices (Irwin , 2015).

Oil_Price $=($ Europe Brent Spot Price x PKR $) / \mathrm{CPI}$ 
Majority of Pakistan's exports as well as imports are in dollars, and exchange rate fluctuations do affect the cost of production as well as balance of trade. So we incorporated exchange rate as second independent variable. The real rates are used as a proxy for exchange rate. The data for KSE 100 index is obtained from Yahoo finance. While the prices of Brent oil is obtained from the official website of U.S. Energy Information Administration (EIA). The data for Exchange rate and CPI (Base year 2010) are collected from the website of IMF.

Figure 2: Oil Prices

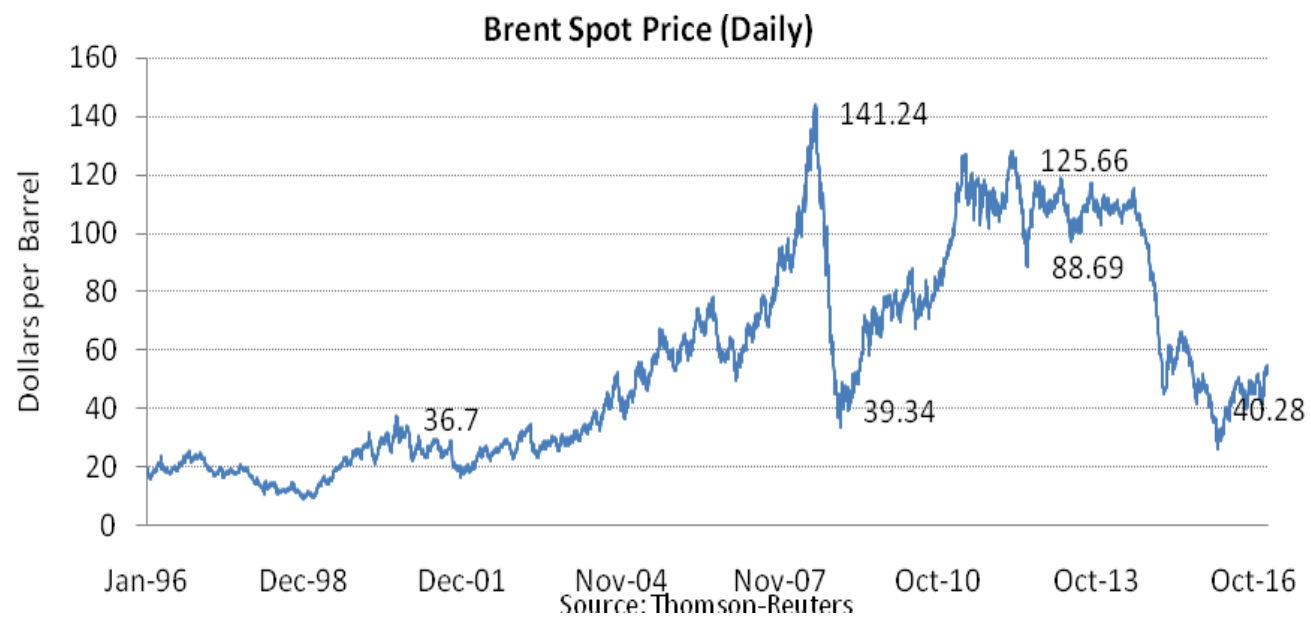

\subsection{Model Specification}

We have used different time series models to examine the relationship between stock returns, oil prices and exchange rate. First, Johansen Cointegration test was applied to establish long run relationship between stock returns, oil prices and exchange rate (Johansen, 1991).

$$
R_{-} K S E_{i, t}=\alpha_{1}+\sum_{i=1}^{n}\left(\beta_{1 i} \text { Oil_Price }_{i, t}\right)+\sum_{i=1}^{n}\left(\gamma_{1 i} F R X_{i, t}\right)+\mu_{1 t}
$$

$R \_K S E_{i, t}$ is the stock returns, Oil_Pirce $e_{i, t}$ is the oil prices, $F R X_{i, t}$ is the exchange rate and $\mu_{1 t}$ is error term.

As long run relationship was established in all data sets by Johansen Cointegration test (discussed in section 4), we applied Vector Error Correction Model (VECM) to establish the long run and short relationship or the speed or partial readjustment towards the equilibrium (Zhang \& Cai, 2010).

$$
\Delta R \_K S E_{t}=\alpha_{1}+\beta_{1} \Delta \text { Oil_Price }_{t}+\beta_{2} \Delta R \_K S E_{t}+\beta_{3} \Delta F R X_{t}+\mu_{t-1}
$$

Further to explore the effect of innovation or exogenous shock in dependent variables and its impact on dependent variable we applied Impulse Response Functions (Maghyereh, 2004). To find the effect of one variable on the other and to identify unidirectional/bidirectional relationship, we have used Pairwise Granger Causality Tests (Chang, 2010) 


$$
R_{-} K S E_{t}=\sum_{i=1}^{n}\left(\alpha_{1 i} \text { Oil_Price }_{t-i}\right)+\sum_{i=1}^{n}\left(\beta_{1 i} F R X_{t-i}\right)+\sum_{i=1}^{n}\left(\gamma_{1 i} R \_K S E_{t-i}\right)+\mu_{1 t}
$$

\section{Results and Analysis}

In first step Augmented Dickey-Fuller (ADF) test was used to identify the existence of unit root. All variables in each data set were non stationary at level $\mathrm{I}(0)$ and stationary at first difference I(1). This means all variables are integrated of same order and we can apply Johansen Cointegration test.

\subsection{Johansen Cointegration Test}

To confirm the long run relationship between variables we used Johansen Cointegration test. The result of Johansen Cointegration of all data sets (at level I(0)) and time period are compiled in Table 1. We opted for Trace test to confirm the long run relationship of our independent and dependent variables. All data sets confirm the long run association or movement in same direction for stock returns, oil prices and exchange rate. In daily data, from 2nd January, 2001 to $31^{\text {st }}$ December, 2008, and monthly data, for the time period 2001-M1 to 2008- M52, indicates 2 cointegrating equations at 5\% significance level. While rest of the four data sets, for both demand and supply driven time period, confirms 1 cointegrating equations at 5\% significance level. Now we can use VECM to confirm the long run and short run association among variables.

\subsection{Vector Error Correction Model}

The results of VECM for samples and time periods are shown in Table 2. We use 3 Lags for our daily data sample for both time periods of, $2^{\text {nd }}$ January, 2001 to $31^{\text {st }}$ December, 2008 and $2^{\text {nd }}$ January, 2009 to $30^{\text {th }}$ December, 2016, based on Akaike information criterion (AIC) and Final Prediction Error (FPR). For remaining samples we used 2 Lags based on AIC in their respective samples. For each sample we reported only the target or main model of VECM, where stock returns is the dependent variable. The results in Table 3, show the coefficient of our main model (where stock returns, (R_KSE) is dependent variable) and their respective probability values. The $\mathrm{C}(1)$ is the coefficient of cointegrating model of each sample and it show the error correction term or speed of adjustment towards equilibrium. The long run causality of variables will be established if the coefficient of $\mathrm{C}(1)$ is negative and significant, as it is the case in all samples except in sample of daily data, Jan-2009 to Dec- 2016, in Table 3. So we can confirm that there is long run causality running from exchange rate (FRX) and oil prices (Oil_Price) to stock returns (R_KSE).

Similarly, to check the short term causality, we have used VEC Granger Causality/Block Exogeneity Wald Tests as show in Table 4. The null hypothesis Oil_Price (lag 1 and lag 2) cannot cause stock returns (R_KSE)) for oil prices and exchange rate (FRX (lag 1 and lag 2) cannot cause stock returns (R_KSE)) are accepted at 5 percent significance level for all samples. This confirms that there is no short term causality between stock return and oil prices, and exchange rate.

\subsection{Granger Causality}

Engel and Granger suggest that if cointegration exits between two variables in long run, then, there must be either unidirectional or bi-directional Granger-causality between those variables. The overall results in Table 5 of the granger causality confirm that during the demand driven oil price shock, the oil prices granger cause stock returns 
and stock returns granger cause oil prices for daily and weekly samples. So there is bidirectional relationship. Whereas unidirectional association is found in monthly data, such as oil prices granger cause stock returns. No other variable show any presence of granger causality across the samples except in weekly sample (2001-2008), stock return granger cause exchange rate. As the granger causality test does not tell us the whole story about the interactions among the variables, we implied impulse response functions.

\section{Table 1: Unrestricted Johansen Cointegration Trace Test}

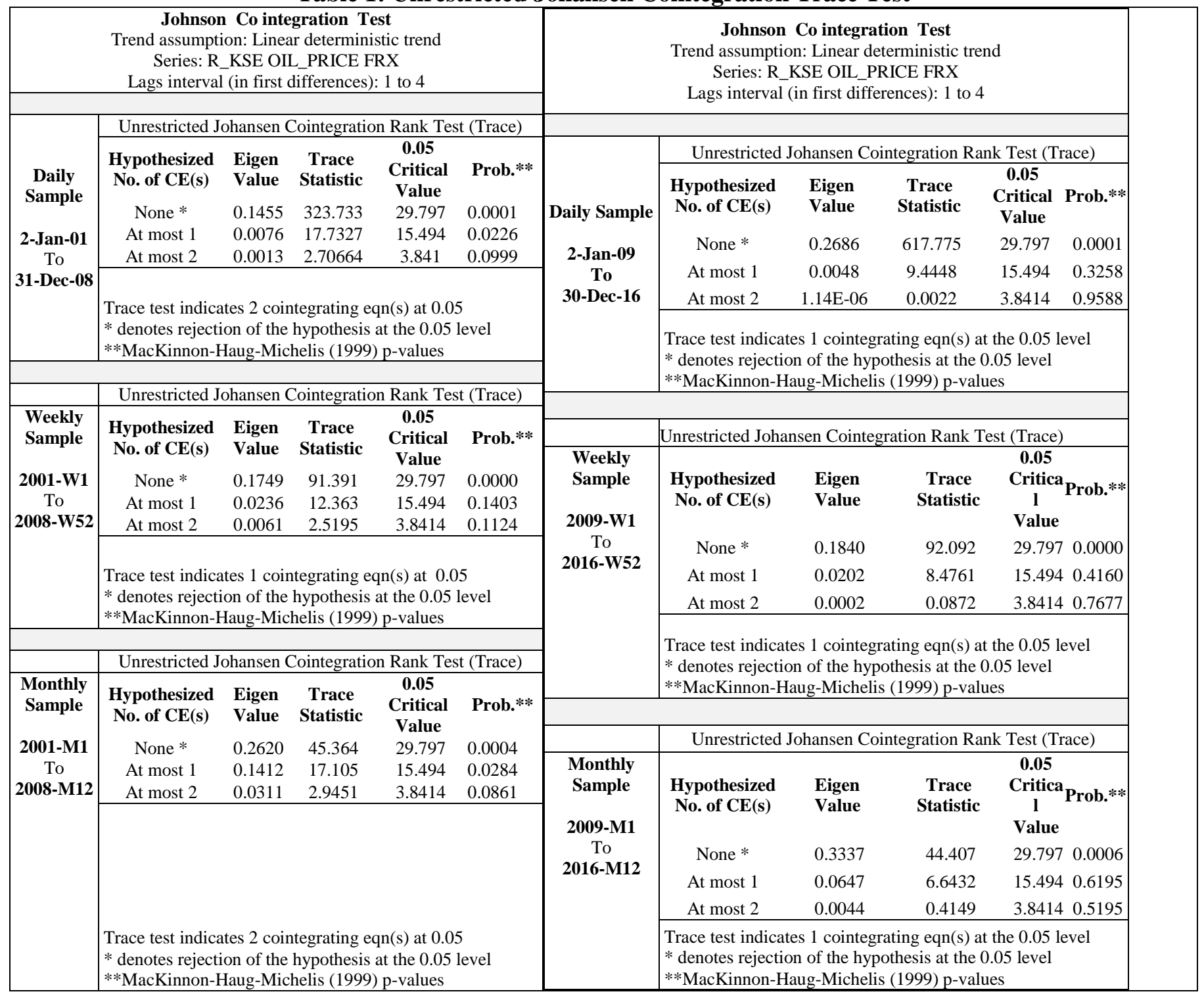


Table 2: Vector Error Correction Estimates

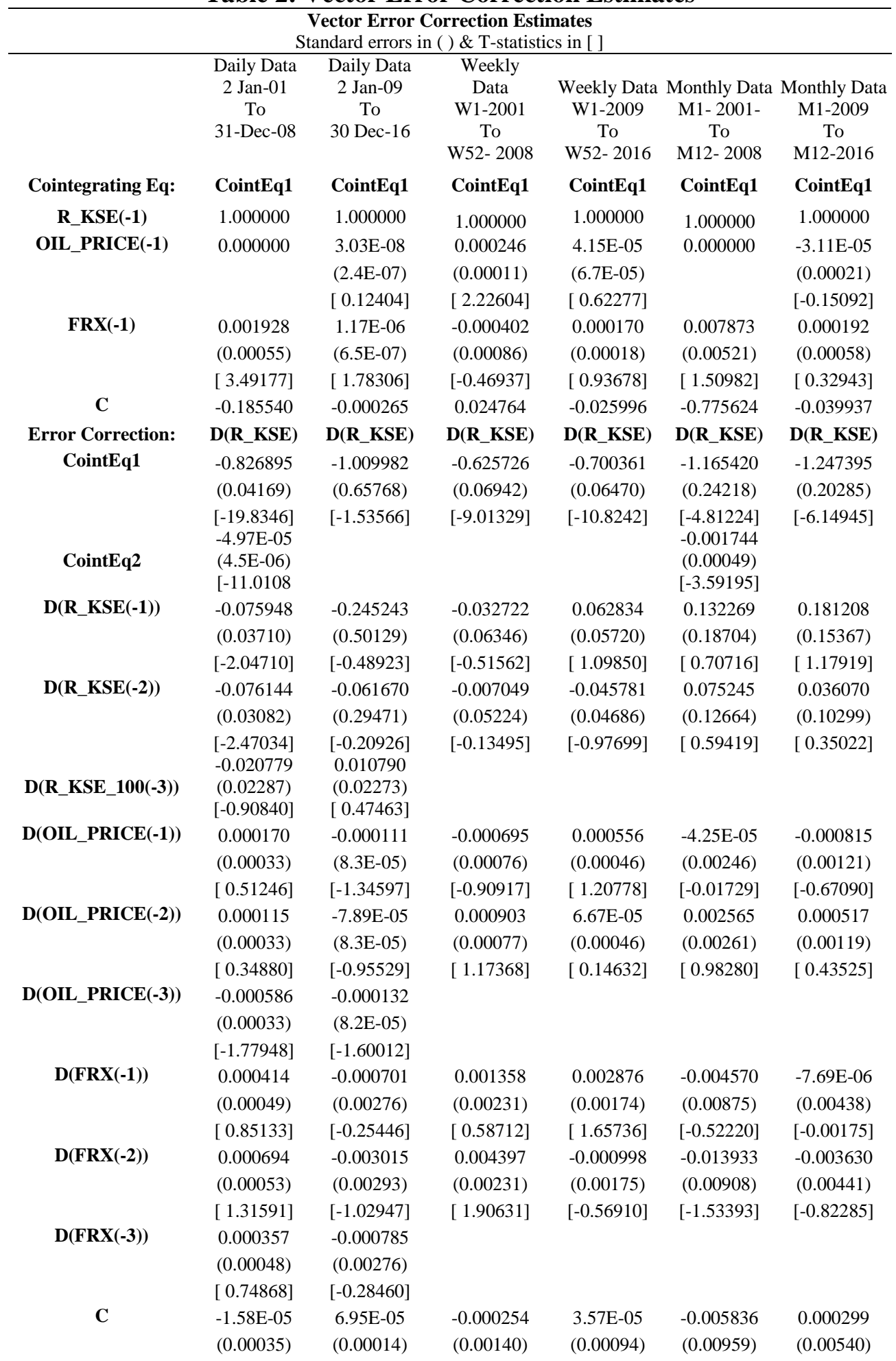


Journal of Business and Tourism

Volume 03 Number 02

\begin{tabular}{ccccccc} 
& & & \multicolumn{3}{c}{ July-December, 2017} \\
R-squared & {$[-0.04486]$} & {$[0.49987]$} & {$[-0.18051]$} & {$[0.03778]$} & {$[-0.60869]$} & {$[0.05537]$} \\
Adj. R-squared & 0.453164 & 0.650751 & 0.323270 & 0.352428 & 0.483290 & 0.569016 \\
\hline
\end{tabular}

Table 3: Long Run Causality

\begin{tabular}{|c|c|c|c|c|c|c|}
\hline \multicolumn{7}{|c|}{$\begin{array}{c}\text { Dependent Variable: D(R_KSE) } \\
\text { Method: Least Squares } \\
\end{array}$} \\
\hline & $\begin{array}{c}\text { Daily Data } \\
\text { 2 Jan-01 } \\
\text { To } \\
\text { 31-Dec-08 }\end{array}$ & $\begin{array}{c}\text { Daily Data } \\
\text { 2 Jan-09 } \\
\text { To } \\
30 \text { Dec-16 }\end{array}$ & $\begin{array}{c}\text { Weekly } \\
\text { Data } \\
\text { W1-2001 } \\
\text { To } \\
\text { W52- } 2008\end{array}$ & $\begin{array}{c}\text { Weekly } \\
\text { Data } \\
\text { W1-2009 } \\
\text { To } \\
\text { W52- } 2016\end{array}$ & $\begin{array}{c}\text { Monthly Data } \\
\text { M1- } 2001 \\
\text { To } \\
\text { M12- } 2008\end{array}$ & $\begin{array}{c}\text { Monthly } \\
\text { Data } \\
\text { M1-2009 To } \\
\text { M12-2016 }\end{array}$ \\
\hline & $\mathrm{C}(1)$ & $\mathrm{C}(1)$ & $\mathrm{C}(1)$ & $\mathrm{C}(1)$ & $\mathrm{C}(1)$ & $\mathrm{C}(1)$ \\
\hline Coefficient & -0.8269 & -1.0033 & -0.6257 & -0.7004 & -1.1654 & -1.2474 \\
\hline Std. Error & 0.0417 & 0.6575 & 0.0694 & 0.0647 & 0.2422 & 0.2028 \\
\hline t-Statistic & -19.8346 & -1.5260 & -9.0133 & -10.8242 & -4.8122 & -6.1494 \\
\hline Prob. & 0.0000 & 0.1272 & 0.0000 & 0.0000 & 0.0000 & 0.0000 \\
\hline R-Squared & 0.4532 & 0.6509 & 0.3233 & 0.3524 & 0.4833 & 0.5690 \\
\hline Adj R-squared & 0.4501 & 0.6491 & 0.3116 & 0.3412 & 0.4341 & 0.5335 \\
\hline Prob (F-Stat) & 0.0000 & 0.0000 & 0.0000 & 0.0000 & 0.0000 & 0.0000 \\
\hline Durbin-Watson & 1.9976 & 2.0025 & 1.9745 & 2.0336 & 1.8656 & 2.0631 \\
\hline
\end{tabular}

Table 4: Short Run Causality

\begin{tabular}{ccccc}
\hline \multicolumn{5}{c}{ VEC Granger Causality/Block Exogeneity Wald Tests } \\
Dependent Variable: D(R_KSE)
\end{tabular}


Table 5: Pairwise Granger Causality

\begin{tabular}{|c|c|c|c|c|}
\hline \multicolumn{5}{|c|}{ Pairwise Granger Causality Tests } \\
\hline \multirow{5}{*}{$\begin{array}{c}\text { Daily Data } \\
2 \text { Jan-01 } \\
\text { To } \\
\text { 31-Dec-08 }\end{array}$} & Null Hypothesis: & Obs & F-Statistic & Prob. \\
\hline & OIL_PRICE does not Granger Cause R_KSE & 1953 & 5.11705 & 0.0061 \\
\hline & R_KSE does not Granger Cause OIL_PRICE & 1953 & 8.60055 & 0.0002 \\
\hline & FRX does not Granger Cause R_KSE & 1953 & 1.07129 & 0.3428 \\
\hline & R_KSE does not Granger Cause OIL_PRICE & 1953 & 0.08733 & 0.9164 \\
\hline \multirow{4}{*}{$\begin{array}{c}\text { Daily Data } \\
2 \text { Jan-09 } \\
\text { To } \\
\text { 30 Dec-16 }\end{array}$} & OIL_PRICE does not Granger Cause R_KSE & 1948 & 0.90472 & 0.4380 \\
\hline & R_KSE does not Granger Cause OIL_PRICE & 1948 & 0.34833 & 0.7904 \\
\hline & FRX does not Granger Cause R_KSE & 1948 & 0.29688 & 0.8277 \\
\hline & R_KSE does not Granger Cause OIL_PRICE & 1948 & 0.35522 & 0.7854 \\
\hline \multirow{4}{*}{$\begin{array}{c}\text { Weekly Data } \\
\text { W1-2001 } \\
\text { To } \\
\text { W52- } 2008\end{array}$} & OIL_PRICE does not Granger Cause R_KSE & 414 & 3.69078 & 0.0258 \\
\hline & R_KSE does not Granger Cause OIL_PRICE & 414 & 4.05506 & 0.0180 \\
\hline & FRX does not Granger Cause $\mathrm{R} \_$KSE & 414 & 0.58846 & 0.5557 \\
\hline & R_KSE does not Granger Cause OIL_PRICE & 414 & 4.05506 & 0.0180 \\
\hline \multirow{4}{*}{$\begin{array}{c}\text { Weekly Data } \\
\text { W1-2009 } \\
\text { To } \\
\text { W52- } 2016\end{array}$} & OIL_PRICE does not Granger Cause R_KSE & 414 & 0.44540 & 0.6409 \\
\hline & R_KSE does not Granger Cause OIL_PRICE & 414 & 0.37284 & 0.6890 \\
\hline & FRX does not Granger Cause R_KSE & 414 & 0.99556 & 0.3704 \\
\hline & R_KSE does not Granger Cause OIL_PRICE & 414 & 0.11894 & 0.8879 \\
\hline \multirow{4}{*}{$\begin{array}{c}\text { Monthly Data } \\
\text { M1- 2001- } \\
\text { To } \\
\text { M12- } 2008\end{array}$} & OIL_PRICE does not Granger Cause R_KSE & 94 & 4.15906 & 0.0188 \\
\hline & R_KSE does not Granger Cause OIL_PRICE & 94 & 0.94247 & 0.3935 \\
\hline & FRX does not Granger Cause R_KSE & 94 & 0.17358 & 0.8409 \\
\hline & R_KSE does not Granger Cause OIL_PRICE & 94 & 0.51338 & 0.6002 \\
\hline \multirow{4}{*}{$\begin{array}{c}\text { Monthly Data } \\
\text { M1-2009 } \\
\text { To } \\
\text { M12-2016 }\end{array}$} & OIL_PRICE does not Granger Cause R_KSE & 94 & 0.03134 & 0.9692 \\
\hline & R_KSE does not Granger Cause OIL_PRICE & 94 & 0.11364 & 0.8927 \\
\hline & FRX does not Granger Cause R_KSE & 94 & 0.86928 & 0.4228 \\
\hline & R_KSE does not Granger Cause OIL_PRICE & 94 & 0.25187 & 0.7779 \\
\hline
\end{tabular}

\subsection{Impulse Response Function}

The impulse response functions are widely used to trace the effect of innovation or exogenous shock in one variable on all other variables. The test for impulse response function traces out the impact of shock or innovation (One Standard Deviation) in one variable on all the other variables. Table 6 shows the responses of stock returns one standard deviation shocks in independent variables in different samples. The response of stock returns was checked for next 10 periods (Days, Weeks, and Months). There is negative response of stock returns to oil price shocks across all samples during demand driven period. This show that increase in oil prices will affect the stock returns 
negatively. The response of stock return to exchange rate is positive in daily and weekly samples. For monthly data there is considerable variation. It is positive initially, but shows negative trend after first period (month), then goes positive after third period.

In supply driven oil shocks, the effect of oil prices and exchange rate invocations have also considerable effects on stock returns. The response of stock returns to oil prices is mix across the samples. But generally after second period there is slight positive association, which completely erodes at fourth period. Similarly the shocks in exchange rate have mix results. A positive change is observed in second period of weekly sample and negative impact is observed in third period of monthly sample.

Table 6: Impulse Response Function

Impulse Response Function

Response to Cholesky One S.D. Innovation

Daily Data

2 Jan-01

To

31-Dec-08
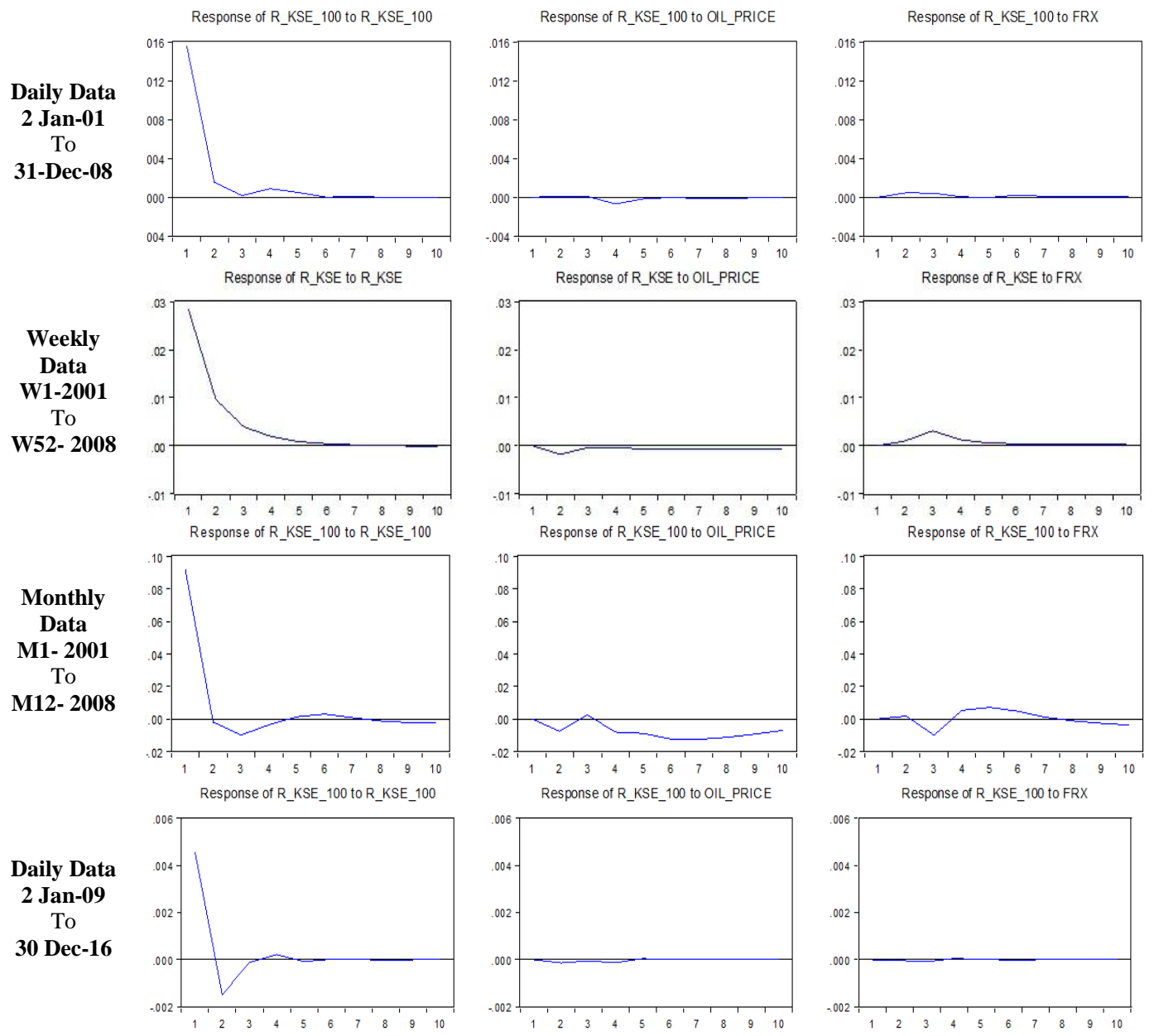

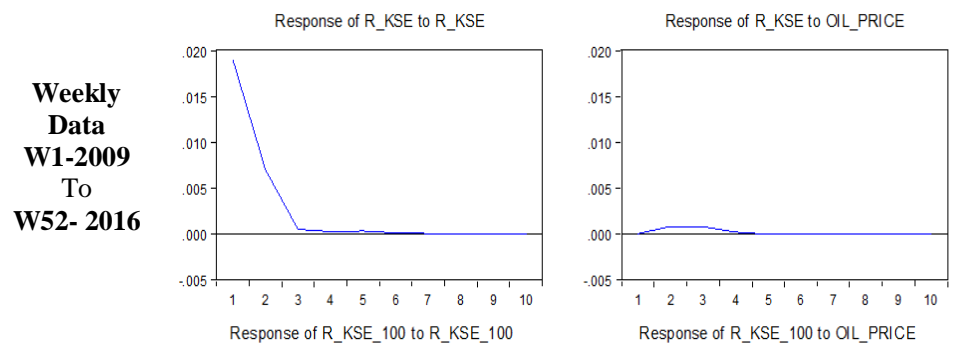

Response of R_KSE to FRX
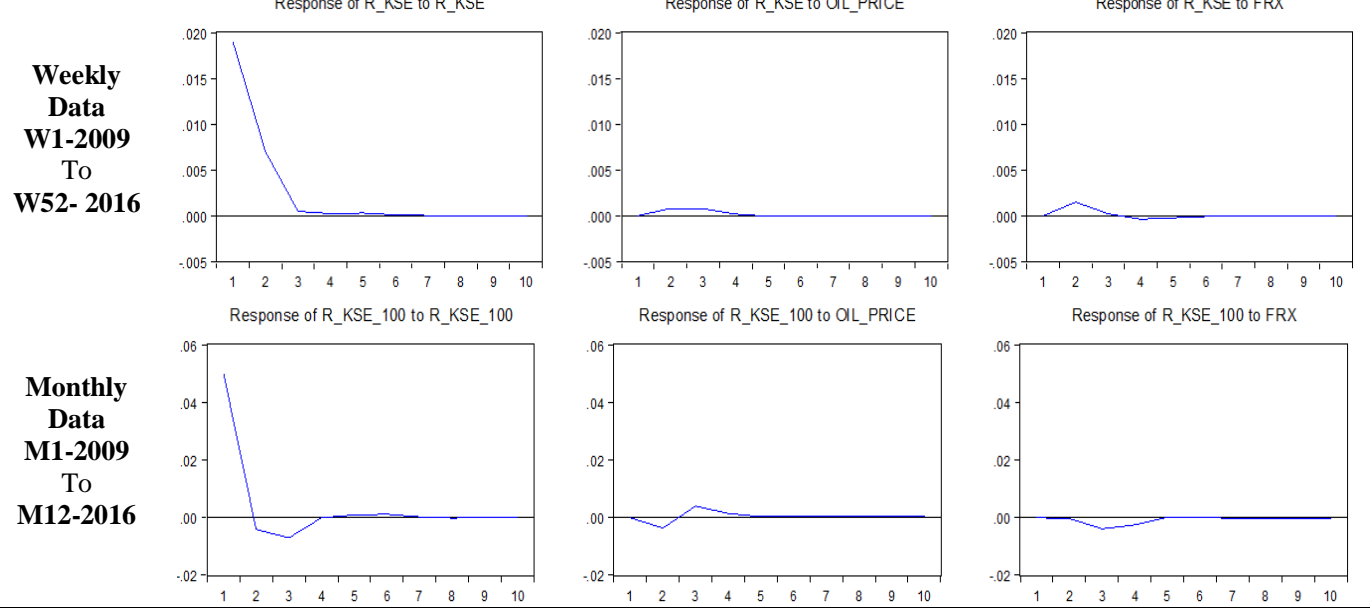

Response of R_KSE_-100 to FRX

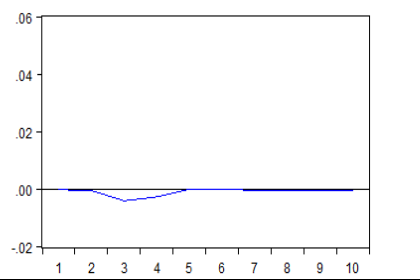

\section{Conclusion}

Researchers have been historically intrigued by oil prices because of its implications for the economy and corporations, at global and national levels, especially of the developed world. But lately, the subject matter has attracted the attention of researchers from developing world, with changing scenarios and its importance. The objective of this study was to examine the co-movement of oil prices, stock returns and exchange rate in the period of oil demand (2001-2008) and supply shock (2009-2016). For the purpose, Pakistan was selected as a sample country due to its dependency on oil import and having vibrant and fast growing stock market. The association of oil prices against stock returns is investigated on daily, weekly and monthly basis, due to high volatility in oil prices and stock prices of Pakistan. Consistent with the findings of Nandha and Faff (2006), the results of Johansen Cointegration and vector error correction models confirmed the long run relationship between oil prices and stock returns in all six samples (daily, weekly and monthly data for oil supply and demand driven shocks). But in short term, the oil prices are not associated with the changes in stock returns; thus suggest that short run volatility in oil prices doesn't affect the stock prices. Furthermore, during demand driven oil prices shock, results confirm bi-directional relationship between oil prices and stock returns in daily and weekly samples. Whereas, unidirectional association is found in monthly data such as oil prices granger causes stock returns. Furthermore, the exogenous shock of one standard deviation in oil demand driven shocks has negative but insignificant response in stock returns. While in supply driven oil prices phase, mix results were observed such as; after second period weak positive association is reported which completely erodes at fourth period. As a whole for monthly data, there is considerable variation in both phases.

\section{References}

Ansar I. \& Asghar N. (2013). The impact of oil prices on stock exchange and CPI in Pakistan. Journal of Business and Management, 7(6), 32-36.

Apergis, N. \& Miller S. M. (2008). Do structural oil-market shocks affect stock prices? Economics Working Papers. Paper 200851.

http://digitalcommons.uconn.edu/econ_wpapers/200851 
Arouri, M. E. H. (2011). Does crude oil move stock markets in Europe? A sector investigation. Economic Modeling, 28(4), 1716-1725.

Arouri, M. E. H., \& Fouquau, J. (2009). How do oil prices affect stock returns in GCC markets? An asymmetric Johansen Cointegration approach.

Arouri, M.E.H., Boubaker, S. \& Nguyen, D. K. (2013). Emerging Markets and the Global Economy: A handbook. Academic Press, 2013.

Arouri, M.E.H., Lahiani, A. \& Nguyen, D.K. (2011). Return and Volatility transmission between world oil prices and stock market of the GCC countries. Economic Modelling, 28(4), 1815-1825.

Arouri, M. E. H., \& Nguyen, D. K. (2010). Oil prices, stock markets and portfolio investment: evidence from sector analysis in Europe over the last decade. Energy Policy, 38(8), 4528-4539.

Arshjad, R. \& Bashir, A. (2015). Impact of oil and gas prices on stock returns: Evidence from Pakistan's energy intensive industries. International Review of Social Sciences, 3(4), 156-168.

Baffes, J., Kose, M. A. K., Ohnsorge, F. \& Stocker, M. (2015). The great plunge in oil prices: causes, consequences, and policy responses. Development Economic World Bank Group.

Barberis, N. (2000). Investing for the long run when returns are predictable. The Journal of Finance, 55(1), 225-264.

Bartov, E., \& Bodnar, G. M. (1994). Firm valuation, earnings expectations, and the exchange- rate exposure effect. The journal of Finance, 49(5), 1755-1785.

Basher, S. A. \& Sadorsky, P. (2006). Oil price risk and emerging stock markets. Global Finance Journal, 17, 224-251.

Bernanke, B. S., Gertler, M., Watson, M., Sims, C. A., \& Friedman, B. M. (1997). Systematic monetary policy and the effects of oil price shocks. Brookings papers on economic activity, (1), 91-157.

Bhar, R., \& Nikolova, B. (2009). Return, volatility spillovers and dynamic correlation in the BRIC equity markets: An analysis using a bivariate EGARCH framework. Global Finance Journal, 19(3), 203-218.

Bjørnland, H. C. (2009). Oil price shocks and stock market booms in an oil exporting country. Scottish Journal of Political Economy, 56(2), 232-254.

Bodnar, G. M., \& Gentry, W. M. (1993). Exchange rate exposure and industry characteristics: evidence from Canada, Japan, and the USA. Journal of international Money and Finance, 12(1), 29-45.

Bouri, E. (2015). Return and volatility linkages between oil prices and the Lebanese stock market in crisis periods. Energy, 89, 365-371.

Boyer, M. M., \& Filion, D. (2007). Common and fundamental factors in stock returns of Canadian oil and gas companies. Energy Economics, 29(3), 428-453.

Broadstock, D.C. \& Filis, G. (2014). Oil price shocks and stock market returns: New evidence from the United State and China. Journal of International Financial Markets, Institutions and Money, 33, 417-433.

Chang, C. C. (2010). A multivariate causality test of carbon dioxide emissions, energy consumption and economic growth in China. Applied Energy, 87(11), 35333537. 
Chen, N. F., Roll, R., \& Ross, S. A. (1986). Economic forces and the stock market. Journal of Business, 383-403

Colombo, J. (2015). Is Crude Oil About To Plunge Below $\$ 40$ ?. Forbes , Retrieved from: https://www.forbes.com/sites/jessecolombo/2015/11/15/is-crude-oil-aboutto-plunge-below-40/\#1c792ecc47fb

Cong, R. G., Wei, Y. M., Jiao, J. L., \& Fan, Y. (2008). Relationship between oil price shocks and stock markets: Empirical analysis for China. Energy Economics, 36 3544-3553.

Cunado, J., \& de Gracia, F. P. (2014). Oil price shocks and stock market returns: Evidence for some European countries. Energy Economics, 42, 365-377.

Degianakis, S., Filis, G. \& Floros, C. (2011). Dymanic correlation between stock market and oil prices: The case of oil-importing and oil-exporting countries. International Review of Financial analysis, 20(3), 152-164.

Degiannakis, S., Fillis, G. \& Kizys, R. (2014). The effects of oil price shocks on stock market volatility: Evidence from European data. The Energy Journal, Vol (35), 35-56.

El Sharif, I., Brown, D., Nixon, B., \& Russell, A. (2005). Evidence of the nature and the extent of the relationship between oil prices and equity values in the UK. Energy Economics. 27(6), 819-830.

Faff, R. W. \& Brailsford T. J. (1999). Oil price risk and the Australian stock market. Journal of Energy Finance and Development, 4, 69-87.

Farid, A. \& Ashraf J. (1995). Volatility at Karachi Stock Exchange. The Pakistan Development Review, 34(4), 651-657.

Fernández, A., Schmitt-Grohé, S., \& Uribe, M. (2017). World shocks, world prices, and business cycles: An empirical investigation. Journal of International Economics.

Filis, G. (2014). Time-varrying co-movments bteweeen stock market returns and oil price shocks. International Journal of Energy and Statistics, 2(1), 27-42.

Grinblatt, M., \& Keloharju, M. (2000). The investment behavior and performance of various investor types: a study of Finland's unique data set. Journal of Financial Economics, 55(1), 43-67.

Hamilton, J. D. (1983). Oil and the macroeconomy since World War II. The Journal of Political Economy, 228-248.

Hamilton, J. D. (2003). What is an oil shock?. Journal of Econometrics, 113(2), 363398.

Hamilton, J. D. (2009). Causes and consequences of oil shock of 2007-2008. Brooking Papers on Economic Activity, Spring 2009.

Huang, R. D., Masulis, R. W., \& Stoll, H. R. (1996). Energy shocks and financial markets. Journal of Futures Markets, 16(1), 1-27.

Irwin, S. (2015). The Real Price of Natural Gas. Farmdoc Daily, 5(5): 212.

Junaid, M., Hussain, H. \& Altaf, M. (2013). Oil prices and stock returns of KSE (Karachi Stock Exchange). International Business Management, 61, 1713917142.

Johansen, S. (1991). Estimation and hypothesis testing of Johansen Cointegration vectors in Gaussian vector autoregressive models. Econometrica: Journal of the Econometric Society, 1551-1580. 
Jones, C. M., \& Kaul, G. (1996). Oil and the stock markets. The Journal of Finance, 51(2), 463-491.

Jorion, P. (1991). The pricing of exchange rate risk in the stock market. Journal of financial and quantitative analysis, 26(03), 363-376.

Kang, W., Ratti, R. A., \& Yoon, K. H. (2015). The impact of oil price shocks on the stock market return and volatility relationship. Journal of International Financial Markets, Institutions and Money, 34, 41-54.

Katakey, R. (2017). BP Targets \$40 Break-Even Oil Price to Reassure Investors. Bloomberg, Retrieved from: https://www.bloomberg.com/news/articles/201702-28/bp-targets-40-break-even-price-in-4-years-to-reassure-investors

Khan, M. Z. (2014). A Year Of Growth For The Pakistani Capital Market, Dawn. Retrieved from: http://www.dawn.com/news/1154454

Khurrum, R. (2015). Karachi Stock Exchange Weekly Analysis 29 March 2015. Karachi Stock Exchange, PSX, KSC market analysis, tips, reviews. Available on: http://www.karachistockexchange.org/search?updated-max=2015-0228T03:52:00-08:00\&max-results $=10 \&$ start $=40 \&$ by-date $=$ false.

Kilian, L. (2009). Not all oil price shocks are alike: Disentangling demand and supply shocks in the crude oil market. American Economic Review, 99(3), 1053-1069.

Kilian, L. \& Park, C. (2009). The impact of oil price shocks on the U.S. stock market. Internatio,nal Economic Review, 50, 1267-1287.

Kling, J. L. (1985). Oil Price Shock and Stock Market Behavior. The Journal of Portfolio Management, 12 (1), 34-39.

LeBlanc, M., \& Chinn, M. D. (2004). Do high oil prices presage inflation? The evidence from G-5 countries. Business Economics 34, 8-48.

Lin, C. C., Fang, C. R. \& Cheng, H. P. (2010). Relationship between Oil Price Shock and Stock Market: An Empirical Analysis from the Greater China. China Economic Journal, 3(3), 241-254.

Lippi, F., \& Nobili, A. (2012). Oil and the Macroeconomy: a quantitative structural analysis. Journal of the European Economic Association, 10(5), 1059-1083.

Maboudian, E. \& Shokri, K. S. (2015). Reinvestigation of oil price-stock market nexus in Iran: A SVAR approach. Iranian Economic Review, 19(1), 81-90.

Maghyereh, A. (2004). Oil price shocks and emerging stock markets: A generalized VAR approach. International Journal of Applied Econometrics and Quantitative Studies. 1, 27-40.

Milstead, D. (2015). The oil price outlook: A slippery slope for energy stocks. The Globe and Mail. Available on: http://www.theglobeandmail.com/globeinvestor/investment-ideas/the-bottom-for-oil-prices-is-as-clear-asmud/article26439129/. Retrieved on: November 29, 2015.

Mohanty, S. K., Nandha, M., Turkistani, A. Q., \& Alaitani, M. Y. (2011). Oil price movements and stock market returns: Evidence from Gulf Cooperation Council (GCC) countries. Global Finance Journal, 22(1), 42-55.

Moore, E., Raval, A. \&Wigglesworth, R. (2016). Equities and bonds feel impact of $\$ 40$ oil. Financial Times, Retrieved from: https://www.ft.com/content/ed18cb425892-11e6-8d05-4eaa66292c32

Muzamil, H. (2015). Pakistan's energy mix: power and politics. Dawn. Available on: http://www.dawn.com/news/1210831. Retrieved on: November 27, 2015. 
Narayan, P. K., \& Sharma, S. S. (2011). New evidence on oil price and firm returns. Journal of Banking \& Finance, 35(12), 3253-3262.

Negi, P., Chakraborty, A., \& Mathur, G. (2011). Oil price shocks and stock markets in BRIC's long-term price linkages between the equity markets and oil prices: A study of two big oil consuming countries of Asia. Middle Eastern Finance and Economics, 14(2011), 140-151.

Nguyen, C. V. \& Ali, M. M. (2011). Testing the weak efficient market hypothesis using Bangladesh panel data. Banks and Bank Systems, 6(11), 11-15.

Papapetrou, E. (2001). Oil price shocks, stock market, economic activity and employment in Greece. Energy Economics, 23, 511-532.

Paresh, (1993). Modeling the impact of oil prices on Vietnam's stock prices. Journal of Economic Dynamics and Control, 28, 349-366.

Park, J., \& Ratti, R. A. (2008). Oil price shocks and stock markets in the US and 13 European countries. Energy economics, 30(5), 2587-2608.

Raheman, A., Sohail, M. K., Zulfiqar, B. \& Noreen, U. (2012). Oil Prices fluctuations and stock returns-A study on Asia Pacific countries. American Journal of Scientific Research, 43 (2012), 97-106.

Ramos, S. B., \& Veiga, H. (2011). Risk factors in oil and gas industry returns: International evidence. Energy Economics, 33(3), 525-542.

Rapaport, A. A. (2010). Supply and Demand Shocks in the Oil Market and their Predictive Power. Available at SSRN 2472379.

Sadorsky, P. (2001). Risk factors in stock returns of Canadian oil and gas companies. Energy Economics, 23(1), 17-28.

Sadorsky, P. (2008). Assessing the impact of oil prices on firms of different sizes: Its tough being in the middle. Energy Policy, 36(10), 3854-3861.

Siddiqui, M. M. (2014). Oil price fluctuation and stock market performance-The case of Pakistan. Journal of International Business and Economics, 2(1), 47-53.

Salahuddin, S.Z. (March, 2016). How Pakistan can benefit from depressed oil prices. The Express Tribune, Retrieved from

http://tribune.com.pk/story/1065083/tapping-potential-how-pakistan-can-benefitfrom-depressed-oil-prices/

The Nation. (2016). Pakistan Stock Exchange to start operations from 11. Available at: http://nation.com.pk/business/07-Jan-2016/pakistan-stock-exchange-to-startoperations-from-11th

Tsai, C. L. (2015). How do US stock returns respond differently to oil price shocks pre-crisis, within the financial crisis, and post-crisis?. Energy Economics, 50, 4762.

U.S. Energy Information Administration. Official Website. Available on: https://www.eia.gov/dnav/pet/hist/LeafHandler.ashx?n=PET\&s=RBRTE\&f=D, Retrieved on: November 28, 2015.

Yu, J. S., \& Hassan, M. K. (2008, March). Rational speculative bubbles: An empirical investigation of the Middle East and North African (MENA) stock markets.

In Economic Research Forum Working Papers (No. 388).

Zhang, X., \& Cai, G. (2010). Tests on causal relationships between petroleum consumption and economic growth based on VECM model. Journal of Tsinghua University Science and Technology, 50(5), 681-685. 
Zhou, M. \& Shenk, M. (2015) Oil Falls Below \$40 a Barrel for First Time Since 2009. Bloomberg, Retrieved from: https://www.bloomberg.com/news/articles/2015-0820/oil-heads-for-longest-weekly-losing-streak-since-1986-amid-glut. 